\title{
UANG FIAT DAN OPERASI PASAR TERBUKA: TINJAUAN EKONOMI ISLAM
}

\author{
Eja Armaz Hardi
}

UIN Sulthan Thaha Saifuddin Jambi

Email: eja.armaz.hardi@gmail.com

Abstract: This article aims to discuss monetary policy in Indonesia, namely Open Market Operations (OPT) on Islamic economics perspective. OPT known as the monetary instrument, which most often used to achieve policy objectives. In general, monetary targets aimed to stimulate the economic growth and inflation stabilization. OPT's policy products included Bank Indonesia Certificates (SBI), Sharia Bank Indonesia Certificates (SBIS), Bank Indonesia Wadiah Certificates (SWBI), Government Securities (SUN), Sukuk, Private Bonds, Rupiah Interventions (IR), and Loan Facilities Bank Indonesia (FASBI) which is traded on the money market; the primary market and the secondary market with an auction system. Currently, All OPT products based on fiat money. The buy and sell system of OPT products uses a discount system and interest rates. Money plays an important role in the economy, so the policy of monetary contraction and expansion of the amount of money circulating in society will affect the velocity of money. With a descriptive analysis, this article analyzes the role of fiat money from the perspective of Islamic economics. This article argues that the three schools of thought in Islamic economics agree that the function of money used as a means of transaction, investment, and precaution. As an exchange style, money unable to be used as a means of future speculation. Thus, the Islamic economy views that underlying of Islamic monetary policy based on the productivity of the real sector and oriented to the welfare of society.

Keywords: Open Market Operations, Monetary, Money, Islamic Economy

Abstrak: Artikel ini bertujuan membahas kebijakan moneter di Indonesia yaitu Operasi Pasar Terbuka (OPT) dalam perspektif ekonomi Islam. OPT merupakan instrumen moneter yang paling sering digunakan untuk mencapai sasaran kebijakan. Secara umum sasaran moneter diperuntukkan pada pertumbuhan ekonomi dan stabilisasi inflasi. Produk kebijakan OPT di antaranya adalah Sertifikat Bank Indonesia (SBI), Sertifikat Bank Indonesia Syariah (SBIS), Sertifikat Wadiah Bank Indonesia (SWBI), Surat Utang Negara (SUN), Sukuk, Obligasi Swasta, Intervensi Rupiah (IR), dan Fasilitas Pinjaman Bank Indonesia (FASBI) yang diperjual belikan di pasar uang; pasar primer dan pasar sekunder dengan sistem lelang. Seluruh produk OPT yang beredar saat ini berbasis uang fiat. Sistem jual beli produk OPT menggunakan sistem diskonto dan tingkat suku bunga. Uang memainkan peran penting dalam perekonomian, sehingga kebijakan kontraksi dan ekspansi moneter jumlah uang yang beredar di masyarakat akan mempengaruhi velositas uang yang beredar. Dengan analisis deskriptif artikel ini mengalisis peran uang fiat ditinjau dari perspektif ekonomi Islam. Artikel ini menyimpulkan bahwa pandangan tiga mazhab dalam ekonomi Islam sepakat bahwa fungsi uang digunakan sebagai alat transaksi, investasi, dan berjaga-jaga. Sebagai ala tukar, uang tidak dapat dijadikan sarana spekulasi masa depan. Dengan demikian ekonomi Islam memandang bahwa, kebijakan moneter Islam setidaknya harus berbasis pada produktivitas sektor riil dan berorientasi kepada kesejateraan masyarakat.

Kata Kunci: Operasi Pasar Terbuka, Moneter, Uang, Ekonomi Islam

\section{A. PENDAHULUAN}

Stabilitas perekonomian domestik dapat dicapai dengan menjaga kesehatan sektor moneter. Pengendalian laju Inflasi dan peningkatan pertumbuhan PDB merupakan tujuan akhir dari implementasi rumusan kebijakan ekonomi suatu negara. Kebijakan ekonomi merupakan salah satu dari perlbagai bentuk kebijakan yang dapat ditempuh suatu negera untuk 
mengendalikan kedua aspek tersebut. ${ }^{1}$ Kebijakan moneter yang diambil oleh pemerintah secara umum menitik beratkan pengaruh pada penganturan percepatan perputaran uang (velocity of money) dalam perekonomian. Pengaturan percepatan perputaran uang di masyarakat dilakukan dengan cara mengontrol jumlah uang beredar, suku bunga kredit, nilai tukar, dan variabel ekonomi dan keuangan lainnya. ${ }^{2}$ Variable-variabel ini digunakan oleh otoritas moneter yaitu Bank Indonesia (BI) untuk mencapai tujuan akhir dari kebijakan moneter. Instrumen yang digunakan oleh BI dalam merumuskan kebijakan moneter adalah seperti instrument Operasi Pasar Terbuka (OPT), Intervensi Rupiah (IR)/FASBI, Stabilisasi Valuta Asing, Fasilitas Diskonto, Giro Wajib Minimun (GWM), Sertifikat Wadiah Bank Indonesia (SWBI). ${ }^{3}$

Beberapa penelitian yang mengkaji tentang instrumen OPT yang digunakan oleh BI dinyatakan bahwa masing-masing instrumen saling berkaitan satu dengan yang lainnya. Akan tetapi, respon impuls pasar uang antar bank, khususnya respon sektor syariah terhadap instrumen Sertifikat Bank Indonesia (SBI) sangat seimbang, sedangkan Sertifikat Bank Indonesia Syariah (SBIS) merespon negatif dan lebih seimbang, walaupun masih terpengaruhi oleh SBI yang bersifat konvensional. ${ }^{4}$ Temuan lain menyatakan bahwa bahwa SBI, SBIS, Pasar Uang Antar Bank (PUAB) dan Pasar Uang Antar Bank Syariah (PUAS) memberikan respon positif terhadap jumlah uang yang beredar (M2) di masyarakat. ${ }^{5}$ Walaupun demikian, alat yang digunakan dalam mengendalikan percepatan perputaran uang dalam kebijakan moneter saat ini adalah uang fiat. Uang fiat dianggap sebagai alat tukar tidak memiliki nilai intrinsic dan cenderung melahirkan sistam ribawi yang dilarang dalam Islam, sehingga beberapa sarjana berpendapat bahwa bahkan instumen bunga yang digunakan adalah riba yang tidak diperbolehkan untuk menjadi bagian pengendalian moneter dalam perekonomian negara khusus pada sektor perbankan syariah. ${ }^{6}$ Fungsi uang sebagai alat spekulasi dalam teori ekonomi konvensional berbanding terbalik dengan fungsi uang dalam teori ekonomi Islam. Ekonomi Islam hanya memperkenankan uang sebagai alat tukar transaksi. Oleh karena itu, uang fiat yang tidak memiliki resistensi terhadap gejolak ekonomi akan rentan mengalami guncangan. Disamping itu, uang fiat yang dapat bertambah dengan sistem bunga dapat memberikan dampak negatif kepada perekonomian, sehingga menyebabkan tingkat inflasi tidak bisa dikendalikan.

Akan tetapi, saat ini uang fiat menjadi satu-satunya alat ukur untuk melihat tingkat pertumbuhan perekomian negara pada lingkup makro. Pertumbuhan rata-rata Produk Domestik Bruto (PDB) Indonesia periode 2014 hingga 2017 sebesar 4.99 persen, dengan rincian tahun 2014 tumbuh sebesar 5.01 persen, 2015 sebesar 4.88 persen, 2016 sebesar 5.03 persen, dan pada

${ }^{1}$ F.X. Sugiono, Instrumen Pengendalian Moneter: Operasi Pasar Terbuka (Jakarta: Pusat Pendidikan dan Studi Kebanksentralan (PPSK) Bank Indonesia, 2004), hlm. 4-5

${ }^{2}$ Perry Warjoyo, Mekanisme Transmisi Kebijakan Moneter Di Indonesia (Jakarta: Pusat Pendidikan dan Studi Kebanksentralan (PPSK) Bank Indonesia, 2004), hlm. 2

${ }^{3}$ Perry Warjoyo, Mekanisme Transmisi..., hlm. 3

${ }^{4}$ Nursantri Yanti, "Pengaruh SBI, Inflasi dan Nilai Tukar Rupiah Terhadap Transaksi Pasar Uang Antar Bank Syariah," At-Tawassuth Vol III No. 1 2018, hlm. 579

${ }^{5}$ Sakinah Rachman dan Sri Herianingrum, "Pengaruh Instumen Sertifikat Bank Indonesia (SBI), Pasar Uang Antar Bank (PUAB), Sertifikat Bank Indonesia Syariah (SBIS), Pasar Uang Antar Bank Syariah (PUAS) Terhadap M2 di Indonesia Periode 2009-2016," Jurnal Ekonomi Syariah dan Terapan Vol V No. 1 2016, hlm. 8990

${ }^{6}$ Heri Purwanto, "Kebijakan Pengendalian Moneter Di Indonesia Dalam Perspektif Perbankan Syariah22," Syariati: Jurnal Studi Al-Quran dan Hukum Vol III No. 1 2017, hlm. 117 
tahun 2017 PDB Indonesia tumbuh sebesar 5.07 persen. $^{7}$ Pada periode yang sama, rata-rata tingkat inflasi aktual Indonesia sebesar 4.58 persen, dengan rincian 2014 Indonesia mengalami inflasi sebesar 8.36 persen, kemudian turun pada tahun 2015 menjadi 3.35 persen, 2016 sebesar 3.02 persen, dan tahun 2017 sebesar 3.61 persen. ${ }^{8}$ Hubungan negatif antara meningkatnya pertumbuhan ekonomi dan menurunnya inflasi penting untuk dicapai oleh suatu negera dalam rangka menstabilkan kondisi perekonomian domestik.

Stagnansi pertumbuhan PDB nasional dan inflasi nasional kemudian menjadi menarik apabila bila dikaitkan dengan persentase penduduk miskin di Indonesia. Pada periode 2014 hingga 2018, menurut laporan Badan Pusat Statistik (BPS) Indonesia bahwa rata-rata persentase tingkat kemiskinan Indonesia pada periode itu adalah 10.73 persen, dimana 2014 sebesar 10.96 persen, 2015 sebesar 11.13 persen, 2016 sebesar 10.70 persen dan 2017 sebesar 10.12 persen. Kemudian apabila dilihat dari sebaran penduduk miskin antar pulau di Indonesia, pulau Kalimantan menunjukkan persentase terkecil terkait penduduk miskin baik kota maupun desa yaitu 4.33 persen dan 7.60 persen. Sedangkan untuk penduduk miskin tertinggi tingkat kota adalah Bali dan Nusa Tenggara sebesar 9.18 persen dan untuk tingkat desa adalah Maluku dan Irian Jaya sebesar 29.15 persen sebagaimana terlihat pada tabel $01 .^{9}$

Tabel 1. Perbandingan Pertumbuhan Produk Domestik Bruto, Kemisninandan Inflasi (persen)

\begin{tabular}{llllll}
\hline Items & 2014 & 2015 & 2016 & 2017 & Mean \\
\hline PDB & 5 & 4.88 & 5.03 & 5.07 & 4.99 \\
\hline Inflasi & 8.36 & 3.35 & 3.02 & 3,61 & 4.58 \\
\hline Kemiskinan & 10.96 & 11.13 & 10.7 & 10.12 & 10.73 \\
\hline \multicolumn{5}{l}{ Sumber: Berita } & Statistik Indonesia \\
Sumber
\end{tabular}

Negara dengan kebijakan ekonomi moneter bermuara kepada bagaimana negara dapat menciptakan dan memberikan pemerataan kesejahteraan bagi masyarakat. Kesejahteraan dapat dirasakan oleh masyarakat ketika kepentingan konsumen dan kepentingan produsen dapat dipenuhi dengan baik atau produksi dan konsumsi dalam keadaan keseimbangan. ${ }^{10}$ Kondisi equilibrium ekonomi terjadi ketika kedua belah pihak mendapatkan manfaat dari transaksi ekonomi yang dilakukan. Oleh karena itu, beban bunga dari pemanfaatan uag fiat sebagai alat dalam menjalankan kebijakan moneter perlu dikaji lebih mendalam untuk menemukan skema yang tepat agar keseimbangan riil ekonomi dapat tercapai dengan baik. Dari paparan di atas terlihat bahwa persentase pertumbuhan ekonomi dan inflasi sejalan dengan dengan presentase tingkat kemiskinan yang muncul, walaupun secara internal/unit terkait pada kebijakan OPT tersebut memberikan pengaruh signifikan satu sama lain. Disaat yang bersamaan insturmen pokok yang digunakan oleh negara dalam kebijakan moneter adalah pertukaran uang di pasar uang dengan tingkat penambahan tersetentu. Dengan menggunakan pendekatan teori uang dan konsep uang dalam perspektif Islam penulis akan menjawab pertanyaan bagaimana ekonomi

\footnotetext{
${ }^{7}$ Bank Indonesia, "Bank Indonesia,” Bank Indonesia, last modified 2018, diakses 3 Maret , 2019

${ }^{8}$ Subdirektorat Konsolidasi Neraca Produksi Nasional, Produk Domestik Bruto Indonesia Triwulan 2014-2018 (Jakarta, 2018), hlm. 77-80

${ }^{9}$ Badan Pusat Statistik Indonesia, Profil Kemiskinan di Indonesia Maret 2018 (Jakarta, 2018)

${ }^{10}$ N. Grogory Mankiw, Principles of Macroeconomics, 6th Editio. (Mason, USA: South-Western Cangage Learning, 2012), hlm. 136
} 
Islam memandang uang yang digunakan dalam Operasi Pasar Terbuka (OPT)?. Untuk menjawab pertanyaan tersebut, artikel ini menggunakan analisis deskriptif kualitatif dengan memanfaatkan studi terhadap data dan literartur yang relevan. Dalam rangka mendapatkan jawaban atas pertanyaan di atas, artikel ini dibagi menjadi beberapa bahasan. Di antara bahasannya adalah perkembangan kebijakan moneter Indonesia dan OPT, selanjutnya sejarah dan konsep uang yang dikaitkan dengan perspektif Islam, dan pada bagian akhir artikel ini akan mengalalisis keterkaitan OPT dengan uang menurut Islam.

\section{B. METODE PENELITIAN}

Artikel ini merupakan kajian analisis deskriptif kualitatif. Pendekatan yang digunakan dalam artikel ini adalah pendekatan studi kepustakaan (library research). Pemanfaatan pendakatan ini digunakan untuk menganalisis document terkait kebijakan moneter khususnya intrumen Operasi Pasar Terbuka (OPT). Disamping itu, pembacaan literatur relevan seperti teori tentang uang yang ditinjau melalui ekonomi konvensional dan ekonomi Islam juga mengguakan pendekatan ini. Setelah pembacaan literatur dan teks terkait dengan topik pembahasan untuk mendapatkan gambaran dan jawaban yang konprehensif, artikel ini menyajikan dialog teoretik tentang bagaimana uang fiat digunakan dalam basis kebijakan moneter suatu negara.

\section{HASIL DAN PEMBAHASAN}

\section{Kebijakan Ekonomi Negara}

Terdapat perbedaan mendasar pada dua paradigma dalam kajian ekonomi makro setelah wafatnya Keynes. Pertama, mazhab mainstream atau neo-classical, yang mendasarkan pada asumsi makro bahwa aktivitas ekonomi digerakkan oleh agen-agen individu; fungsi produksi yang menciptakan pasar yang bersih, sehingga ekonomi dalam keadaan fullemployment. Kedua adalah post-Keynesian atau strukturalist, yang berasumsi bahwa lembaga bersama-sama dengan pemerintah dan data ekonomi dapat diperiksa secara empiris. ${ }^{11}$ Mazhabmazhab ekonomi konvensional tersebut terus berkembangan sesuai dengan kondisi perekonomian yang semakin lama semakin kompleks, terbuka, cepat, dan hubungan antara negara-negara di dunia tidak dapat dihindari.

Perbedaan kedua pandangan tersebut berimplikasi kepada kebijakan ekonomi yang harus dirumuskan oleh suatu negara. Perbedaan yang signifikan antara teori klasik dan teori modern adalah terletak pada preferensi kebijakan ekonomi yang ditempuh. Mazhab klasik lebih memiliki preferensi mengambil jalur kebijakan moneter dalam mencapai stabilitas ekonomi, sedangkan ekonomi modern cenderung memilih kebijakan fiskal sebagai sarana menuju tujuan kebijakan ekonomi. Akan tetapi keduanya memiliki tujuan yang sama yaitu menciptakan keseimbangan, pertumbuhan ekonomi dan kesejahteraan negara. Disamping itu, apabila negara mengambil jalur kebijakan moneter maka yang dominan berperan adalah Bank Sentral sebagai pusat kebijakan, sedangkan jalus fiskal atau pajak maka yang berperan adalah kementerian keuangan.

${ }^{11}$ Wynne Godley dan Marc Lavoie, Monetary Economics: an Integrated to Credit, Money, Income, Production and Wealth (Great Britain: Antony Rowe Ltd, Chippenham and Eastbourne, 2007), hlm. 1-2 


\section{Kebijakan Moneter Indonesia}

Aktivitas ekonomi dan keuangan dalam suatu negara dipengaruhi oleh peran kebijakan moneter yang ditempuh oleh Bank Sentral. Hal ini dikarenakan kebijakan tersebut ditujukkan pada stabilitas harga dan pertumbuhan ekonomi, seperti perputaran uang dalam perekonomian; perkembangan uang yang beredar; suku bunga; nilai tukar dan lainnya. ${ }^{12}$ Sedangkan di Indonesia, menurut UU No. 23 Tahun 1999 yang diubah dengan UU Nomor. 3 Tahun 2004, tujuan Bank Indonesia (BI) adalah mencapai dan memelihara stabilitas nilai rupiah, stabilitas harga (inflasi), dan nilai tukar rupiah.

Pada tataran praktis setidaknya kebijakan moneter dipengaruhi oleh tiga hal yaitu: (1) perubahan perilaku bank sentral, perbankan, dan para pelaku ekonomi; (2) rentang waktu yang dibutuhkan untuk mencapai sasaran inflasi (lag); (3) perubahan alur transmisi moneter yang sejalan dengan perkembangan ekonomi dan keuangan negara. ${ }^{13}$ Oleh karena itu, dalam rangka merespon perubahan perilaku bank sentral, perbankan dan sektor keuangan diperlukan antisipasi dengan perubahan perilaku tersebut. Dalam hal rentang waktu yang ditempuh tergantun kepada kompleksitas produk-produk keuangan yang digunakan sebagai instrument untuk mencapai sasaran moneter. Perubahan alur yang digunakan dalam perekonomian terbuka maka kondisi moneter dan keuangan negara saling mempengaruhi satu dengan yang lainnya.

Kompleksitas transmisi kebijakan moneter di Indonesia setidaknya dapat dijelaskan melalui dua tahap yaitu: pertama, interaksi yang terjadi di pasar keuangan, yaitu interaksi antara bank sentral dengan perbankan dan lembaga keuangan lainnya dalam aktifitas keuangan; kedua, interaksi yang berkaitan dengan fungsi intermediasi, yaitu interaksi antara perbankan dan lembaga keuangan lainnya dengan para pelaku ekonomi dalam berbagai aktivitas ekonomi di sektor riil. ${ }^{14}$ Beberapa saluran yang digunakan sebagai basis dalam kebijakan moneter adalah uang, kredit, suku bunga, nilai tukar, harga aset, dan ekspektasi.

\section{Operasi Pasar Terbuka}

Sebagaimana disebutkan di atas bahwa kebijakan moneter merupakan salah satu kebijakan yang ditempuh oleh pemerintah untuk meningkatkan kesejahteraan masyarakat dalam suatu negara. Dalam kebijakan moneter kesejahteraan terlihat dari pertumbuhan ekonomi, stabilitas harga, keseimbangan harga dan neraca pembayaran yang tercermin dari pertumbuhan Produk Domestik Bruto (PDB). Dalam mencapai tujuan kebijakan moneter tersebut, bank sental meliputi dua sasaran: sasaran akhir yang biasanya diarahkan untuk mencapai stabilitas harga dan/atau pertumbuhan ekonomi jangka panjang. ${ }^{15}$

Berkembangnya perkonomian negera-negara dari tertutup menjadi terbuka memaksa mereka untuk meninggalkan instrumen kebijakan langsung ke instrumen kebijakan moneter tidak langsung. Di Indonesia instrumen kebijakan langsung mulai dirasa tidak efektif pada awal dekade 80-an yang kemudian beralih kepada kebijakan moneter tidak langsung. Kebijakan moneter tidak langsung ini salah satu yang digunakan adalah Operasi Pasar Terbuka (OPT) yang ditandai dengan keluarnya kebijakan deregulasi keuangan dan perbankan pada tahun 1983. Secara umum OPT diartikan sebagai pembelian atau penjualan surat berharga oleh bank sentral

\footnotetext{
${ }^{12}$ Warjoyo, Mekanisme Transmisi Kebijakan Moneter Di Indonesia, (Jakarta: Pusat Pendidikan dan Studi Kebanksentralan (PPSK) Bank Indonesia, 2004), hlm. 2

${ }^{13}$ Warjoyo, Mekanisme Transmisi... hlm. 4

${ }^{14}$ Warjoyo, Mekanisme Transmisi..., hlm. 6-7

${ }^{15}$ Sugiono, Instrumen Pengendalian Moneter: Operasi Pasar Terbuka, (Jakarta: Pusat Pendidikan dan
} Studi Kebanksentralan (PPSK) Bank Indonesia, 2004), hlm. 6 
baik pada pasar perdana maupun pasar sekunder dengan tujuan memperngaruhi kondisi likuiditas pasar uang, seperti surat berharga penerintah (treasury bills atau T-Bills), surat berharga bank sentral (central bank bills) dan surat berharga swasta (prime commercial papers). ${ }^{16}$ Operasi Pasar Terbuka menjadi instrumen kebijakan yang sering digunakan oleh otoritas moneter, hal ini dikarena instrumen ini berorientasi pasar, keterlibatan bank dan pialang bersifat tidak mengikat, arah kebijakan mudah ditangkap oleh pasar, dan tidak membebankan pajak pada bank. ${ }^{17}$

Selanjutnya dalam rangka mempengaruhi kondisi likuditas pasar uang kebijakan moneter yang tempuh oleh bank sentral dapat melakukan kontraksi kebijakan atau ekspansi kebijakan. Dalam konteks kontraksi, BI menjual SBI dan untuk ekspansi BI membeli kembali SBI (SBI Repo). Dengan kata lain, apabila likuiditas perbankan mengalami surplus maka BI akan menjual surat berharga, sebaliknya apabila permintaan uang mengalami surplus maka BI akan membeli surat berharga tersebut. Implikasi dari jual-beli surat berharga tersebut adalah pada beban yang ditanggung, apabila BI menjual SBI maka beban OPT ditanggung oleh BI, sedangkan apabila OPT menggunakan intervensi valuta asing maka tergantung pada pihak pengelola baik BI atau pemerintah. ${ }^{18}$

Tabel 2. Pergerakan Jumlah Instrumen Moneter Indonesia

Per Desember (milyar rupiah)

\begin{tabular}{ccccccc}
\hline Tahun & SBI & SBIS & SWBI & FASBIS & SBSN & SUN \\
\hline $\mathbf{2 0 1 5}$ & & & & 201,017 & $1,327,436$ \\
\hline $\mathbf{2 0 1 4}$ & & & & 143,901 & $1,101,648$ \\
\hline $\mathbf{2 0 1 3}$ & & 3,455 & & & 118,707 & 908,078 \\
\hline $\mathbf{2 0 1 2}$ & 79,973 & 3,476 & & 15,582 & 98,818 & 757,231 \\
\hline $\mathbf{2 0 1 1}$ & 119,777 & 2,997 & & 17,403 & & \\
\hline $\mathbf{2 0 1 0}$ & 200,113 & 2,997 & & 9,175 & & \\
\hline $\mathbf{2 0 0 9}$ & 255,523 & 4,341 & & 3,386 & & \\
\hline $\mathbf{2 0 0 8}$ & 177,304 & 2,824 & & & & \\
\hline $\mathbf{2 0 0 7}$ & 245,328 & & 2,599 & & & \\
\hline $\mathbf{2 0 0 6}$ & 207,400 & & 2,357 & & & \\
\hline $\mathbf{2 0 0 5}$ & 72,237 & 2,395 & & &
\end{tabular}

Sumber: Data diolah dari www.bi.go.id

Terlihat pada table 2 di atas bahwa instrument yang digunakan oleh BI secara umum terus mengalami peningkatan dari pada periode 2005 hingga 2015. Sertifikat Wadiah Bank Indonesia berakhir pada Maret tahun 2008, sehingga untuk instrument yang menghubungkan BI dan Bank Umum Syariah (BUS) tidak lagi digunakan. Surat Berharga Syariah Negara (SBSN) dan Surat Utang Negara (SUN) menjadi intsrumen yang mengalami peningkatan paling tinggi dalam kurun waktu 4 tahun. Masing-masing SBSN sebesar 98,818 milyar rupiah dan SUN 757,231 milyar rupiah pada tahun 2012 meningkat menjadi 201,017 milyar rupiah dan

\footnotetext{
${ }^{16}$ Sugiyono, Instrumen Pengendalian...hlm. 7-8

${ }^{17}$ Sugiyono, Instrumen Pengendalian...hlm. 7-8

${ }^{18}$ Sugiyono, Instrumen Pengendalian...hlm. 7-8
} 
1,327,436 milyar rupiah pada tahun 2015 .

Sertifikat Bank Indonesia (SBI) mencapai puncak pada tahun 2007 sebesar 245,328 milyar rupiah, sedangkan Sertifikat Bank Indonesia Syariah (SBIS) mencapai angka tertinggi pada tahun 2009 sebesar 4,341 milyar rupiah. Sedangkan FASBIS mengalami peningkatan yang paling tinggi mencapai 460 persen dalam jangka waktu 4 tahun, 3,386 milyar rupiah pada tahun 2009 menjadi 15,582 milyar rupiah pada tahun 2012. Sementara fluktuasi dan pertumbuhan eksponensial masing-masing instrument yang dilakukan oleh BI menandakan adanya upaya kontraksi dan ekspansi dalam rangka mengatur jumlah uang berardar.

\section{Mekanisme Operasi Pasar Terbuka (OPT)}

Selain Sertifikat Bank Indonesia (SBI) dalam mata uang rupiah, Surat Utang Negara (SUN) pada pasar primer atau sekunder Operasi Pasar Terbuka (OPT) yang dilakukan oleh Bank Indonesia (BI) dapat berupa jual-beli valuta asing terhadap rupiah dan Fasilitas Simpanan Bank Sentral (FASBI/Intervensi Rupiah (IR)). SBI dapat diartikan sebagai surat pengakuan hutang jangka pendek dalam nominal rupiah dengan sistem diskonto melalui sistem lelang atau non-lelang.

Surat berharga yang diperjual-belikan oleh BI harus bersifat likuid, syaratnya: (1) diperdagangkan di pasar sekunder dengan harga yang wajar; (2) volume surat berharga memadai untuk kepentingan OPT, dan; (3) diterbitkan secara kontinue dan selalu tersedia setiap saat. ${ }^{19}$ Selain SBI, BI juga menyediakan Sertifikat Wadiah Bank Indonesia (SWBI) sebagai fasilitas penitipan dana bagi bank syariah dengan menggunakan prinsip syariah. kemudian ada FASBI, instrumen ini digunakan oleh BI sebagai kontraksi dan ekspansi memalui mekanisme pinjam meminjam antar bank (PUAB) dengan jangka lebih pendek dari SBI.

Dalam pelaksanaan OPT, BI menetapkan uang primer atau komponennya sebagai sasaran operational dan jumlah uang yang berdar dalam arti sempit maupun dalam arti luas (M1, M2). Lelang SBI adalah penjualan di pasar perdana kepada peserta lelang yang ditunjuk oleh BI yaitu bank, pialan pasar uang dan pialang pasar modal. Disaat yang bersamaan, jumlah SBI yang diterbitkan oleh BI disesuaikan dengan sasaran lelang berdasarkan kuantitas dan kondisi likuiditas perbankan yang disebut dengan stop-out rate (SOR). Kemudian Dewan Gubernur Bank Indonesia (DGBI) setiap minggu melaksanakan Rapat Dewan Gubernur (RDB) untuk melakukan evaluasi terhadap pelaksanaan kebijakan moneter dan menetapkan kebijakan lain yang bersifat prisip dan strategis. ${ }^{20}$

Selanjutnya besaran sasaran lelang tergantung pada kondisi likuditas perbankan yang dipengaruhi oleh: (1) perubahan faktor otonom; (2) posisi jatuh tempo instrumen OPT, dan; (3) strerilisasi/intervensi valuta asing. Kemudian penetapan pemenang lelang oleh Bank IndonesiaScripless Security Settlement System (BI-SSSS) memperhatikan beberapa hal sebagai berikut: (1) penawaran yang diajukan tingkat diskontonya lebih rendah dari SOR yang ditentukan, maka peserta lelang yang bersangkutan akan memperoleh seluruh SBI yang diajukan; (2) penawaran yang diajukan tingkat diskontonya sama dengan SOR yang ditentukan, maka peserta lelang yang bersangkutan dapat memperoleh seluruh jumlah SBI yang diajukan, dan; (3) kuantitas hasil lelang SBI dapat dilakukan penyesuaian dari sasaran kuantitas atau dibatalkan seluruhnya dalam hal SOR yang akan terbentuk daru penawaran lelang di luar batas kewajaran. ${ }^{21}$

\footnotetext{
${ }^{19}$ Sugiyono, Instrumen Pengendalian..., hlm. 18

${ }^{20}$ Sugiyono, Instrumen Penendalian..., hlm. 23

${ }^{21}$ Sugiyono, Instrumen Penendalian..., hlm. 25-26
} 


\section{Sejarah Uang}

Pada masa-masa awal peradaban ketika diasumsikan manusia pada saat itu tidak memiliki kelebihan barang, maka transaksi yang digunakan adalah dengan menggunakan sistem barter. Dalam keadaan ekonomi barter adalah kondisi dimana masyarakat secara langsung bertukar barang untuk barang yang lain. ${ }^{22}$ Kemudian dikarenakan beberapa pelaku ekonomi dan masyarakat mencapai tingkat kesejahteraan, maka disepakatilah untuk menentukan alat tukar dari barang komoditas sebagai alat transaksi. Dengan berkembangnya transaksi sosio-ekonomi masyarakat dan kesepakatan tershadap uang komoditas hanya bersifat lokal dan berbeda-beda saru masyarakat dengan lainya, maka muncul masalah untuk melakukan transaksi diluar komunitas. Oleh karena itu, consensus dari entitas pelaku ekonomi saat itu untuk menentukan alat tukar yang dapat digunakan lebih luas.

Walaupun uang komoditas banyak digunakan dimasyarakat, akan tetapi bahan baku dari emas dan perak dalam bentuk koin lebih banyak digunakan karena ketahanan dan keandalannya. Koin pertama berbahan dasar logam mulia digunakan sebagai uang tanpa tanda muncul di China sekitaran 1000 SM dan sekitar 700 SM di Yunani. Kemudian uang koin dari emas dan perak tersebut diberi tanda pada dua sisi, sebagai contoh uang bertanda tuhan Athena pada bagian depan dan belakang yang dikeluarkan oleh Alexander the Great. Penggunaan uang berbasis emas dan perak ini berlangsung hingga pertengahan abad ke-20, akan tetapi sekarang diganti dengan berbagai macam bentuk uang. ${ }^{23}$

Perkembangan transaksi ekonomi yang semakin luas menyebabkan fase uang logam berakhir, dan disubstitusi dengan uang kertas. Kemunculan pertama uang berbasis kertas pertama adalah di China sekitar tahun 1000 dan di Eropa sekitar tahun 1500 hingga 1700. Pada masa awal, uang kertas di-back up oleh ketersediaan emas dan perak. Dengan demikian, penggunaan uang kertas bertujuan untuk memberikan kemudahan dalam bertransaksi dan lebih mudah untuk dibawa keberbagai tempat. Sebagai contoh, pada awal abad ke-20 Amarika Serikat memiliki mata uang kertas dalam bentuk sertifikat emas yang digunakan sebagai bukti kepemilikan emas dan perak. Untuk mendapatkan sertifikat emas dan perak tersebut masyarakat harus menukarkan emas yang mereka miliki yang kemudian diganti dengan sertifikat tanda kepemilikan emas dan perak. Dalam rangka memudahkan transaksi jual beli, maka pada sertifikat yang dipegang oleh empunya tercantum in gold coin, payable to the beare on demand pada sertifikat emas (US Federal Reserve, 1922) dan Silver Dollar, this certifies that there have been deposit in the treasury (US Federal Reserve, 1908).

Kemudian, uang kertas yang awalnya berbasis emas, dalam artian ia dikeluarkan sesuai dengan cadangan emas yang dimiliki menjadi semakin liar. Disamping pemerintah atau bank menyadari kebutuhan semakin lama semakin meningkat dan orang lebih menyukai penggunaan uang kertas jarang meminta komoditasnya kembali. Beberapa melakukan kecurangan dengan menerbitkan sertifikat emas lebih banyak dari pada cadangan yang ada. ${ }^{24}$ Dengan kata lain bahwa sertifikat yang diterbitkan tidak dapat lagi ditukar menjadi emas atau perak kepada bank, sertifkat tersebut menjadi sertifikat kosong. Selisih dari nilai yang tertera

\footnotetext{
${ }^{22}$ Iraj Toutouchian, Islamic Money and Banking: Integrating Money in Capital Theory (Singapore: John Wiley \& Sons (Asia) Pte. Ltd., 2009), hlm. 1

${ }^{23}$ Lauraence M. Ball, Money, Banking, and Financial Markets, Second. (New York: Worth Publishers, 2012), hlm. 30-1

${ }^{24}$ Lauraence M. Ball, Money, Banking..., hlm. 31-32
} 
pada uang kertas dengan underlying asset atau nilai instrinsik uang inilah yang disebut oleh Irad sebagai bagaimana riba berkembang dimasyarakat. Ia menyebutkan pola transaksi berubah dari Komoditas-Uang-Komoditas (C-M-C) menjadi Uang-Komoditas-Uang (M-C-M) ${ }^{25}$ Perubahan pola tersebut menjadikan uang kertas semakin lama mengalami penyusutan nilai karena digunakan sebagai alat komoditas berdagangan dan tidak lagi sebagai alat tukar. ${ }^{26}$ Hingga saat ini, setelah uang komoditas dan uang fiat bentuk uang terus berkembang menjadi uang kredit, token, uang Bank Sentral, uang bank komersial dan uang substitusi. ${ }^{27}$

\section{Fungsi Uang}

Dalam perspektif ilmu ekonomi konvensional uang adalah kelas aset yang berfungsi sebagai media pertukaran dalam perekonomian, dimana media pertukaran tersebut digunakan oleh pelaku ekonomi untuk membeli barang dan jasa. ${ }^{28}$ Selain itu uang juga berfungsi sebagai satuan hitung dan sebagai sarana penyimpang nilai. ${ }^{29}$ Namun, dalam perkembangannya, fungsi tersebut menjadi berkembang dengan adanya anggapan nilai uang akan berkurang dengan istilah time value of money, sehingga menyebabkan permintaan dan penawaran uang menjadi sulit untuk mencapai tingkat keseimbangan dan menurunkan standar sebagai alat ukur. ${ }^{30}$ Disamping itu, fungsi uang tersebut juga terdapat dua type uang yang digunakan dalam transaksi sehari-hari yaitu uang komoditas dan uang fiat. Uang komoditas adalah barang berharga yang disepakati sebagai alat tukar, sedangkan uang fiat adalah uang yang tidak memiliki nilai intrinsik. ${ }^{31}$

Uang komoditas yang awalnya merupakan barang-barang biasa yang disepakati bersama sebagai alat tukar transaksi, kemudian berbasis emas dan perak sebagaimana disebut di atas. Hingga pertengan abad ke-20 uang komoditas tersebut ditinggalkan dan diganti dengan uang dengan jenis lain yaitu uang fiat. Oleh karena itu hampir seluruh negara dunia saat ini menggunakan uang tersebut. Disebut uang fiat karena keberadaannya sebagai alat tukar ditetapkan oleh pemerintah dan biaya yang dikeluarkan untuk mencetak uang fiat tersebut tidak sama dengan nominal yang tercantum. Dengan kata lain, apabila uang fiat dicabut fungsinya oleh pemerintah maka uang tersebut tidak lagi memiliki nilai atau harga sama sekali.

Sebagimana fungsi uang tersebut di atas, dalam transmisi moneter melalui Operasi Pasar Terbuka (OPT) sepenuhnya memanfaatkan fungsi uang. Sertifikat Bank Indonesia (SBI) misalnya, SBI yang diterbitkan oleh Bank Indonesia (BI) adalah sebagai surat berharga yang dinilai dengan nominal tertentu dan diperjual belikan dengan tingkat diskonto tertentu atau tingkat suku bunga untuk menarik minat lembaga perbankan maupun pialang ikut menjual atau membeli SBI yang diterbitkan. Hal tersebut juga berlaku pada instrumen OPT lainnya seperti SUN, SWBI, SBIS, FASBI, Intervensi Rupiah dan lainnya. Dengan demikian, apabila merujuk kepada definisi uang fiat di atas, apabila uang tersebut suatu ketika dicabut fungsinya oleh pemerintah atau tidak lagi dipercaya oleh masyarkat maka sistem moneter dalam negara cenderung akan mengalami krisis dan berdampak sistemik.

\footnotetext{
${ }^{25}$ Toutouchian, Islamic Money and ..., hlm. 4

${ }^{26}$ Arif Pujiyono, "Dinar dan Sistem Standar Tunggal Emas ditinjau Menurut Sistem Moneter Islam," DInamika Pembangunan Vol I, no. 2 2004, hlm. 144-152

${ }^{27}$ Ansgar Belke dan Thorsten Plleit, Monetary Economics in Globalised Financial Markets (Berlin: Springer, 2009), hlm. 7

${ }^{28}$ Ball, Money, Banking, and..., hlm. 27

${ }^{29}$ Ball, Money, Banking, and..., hlm. 28-29

$144-145$

${ }^{30}$ Pujiyono, "Dinar dan Sistem Standar Tunggal Emas ditinjau Menurut Sistem Moneter Islam.”, hlm.

${ }^{31}$ Ball, Money, Banking, and..., hlm. 30
} 


\section{Uang Perspektif Ekonomi Islam}

Uang dalam konsep ekonomi Islam adalah sebagai milik publik, dalam artian uang harus mengalir dan tidak boleh dibiarkan (idle) dalam kondisi yang tidak produktif, sebab akan menghambat sirkulasi aliran perekonomian. Selanjutnya Islam memandang bahwa uang adalah flow concept dan kapital sebagai stock concept, sedangkan ekonomi konvensional memandang bahwa uang memiliki dua aspek yang bersamaan yaitu ia adalah uang disaat bersamaan ia adalah capital. ${ }^{32}$ Dengan demikian uang menurut perspektif ekonomi Islam adalah uang yang tidak memiliki dua fungsi tersebut pada saat yang bersamaan, sebagai contoh adalah uang berstandarisasi emas atau perak.

Dua koin yang menjadi media transaksi pertukaran di awal pemerintahan Islam adalah pertama berasal dari kekaisaran Roma adalah emas dan perak berasal dari kekaisaran Persia dengan kurs Dinar ke Dirham 1:10 dan kemudian naik menjadi 1:35. ${ }^{33}$ Relevansi Dinar dan Dirham menurut beberapa ekonom muslim memiliki fungsi yang sama dengan uang kertas yang ada hari ini, hal ini dikarenakan pengumpulan zakat dilakukan dengan uang kertas. ${ }^{34} \mathrm{Di}$ samping itu, uang diciptakan untuk mendorong kelancaran arus pertukaran dan menciptakan nilai yang wajar dari pertukaran tersebut. ${ }^{35}$

Berdasarkan QS. Al-Anam: 152, uang dianalogikan sebagai timbangan nilai atas suatu barang yang tugasnya adalah alat pengukur nilai harus memainkan perannya dalam perekonomian dengan adil dalam pembayaran, khususnya pada pembayaran tunda (transaksi akad salam), karena usaha saat ini tidak ada yang menjamin di masa depan (QS. Lukman: 34). ${ }^{36}$ Dalam konteks ini instrumen yang digunakan dalam kebijakan moneter di Indonesia seperti Sertifikat Bank Indonesia (SBI), Sertifikat Bank Indonesia Syariah (SBIS), Intervensi Rupiah (IR), Nilai Tukar, Surat Berharga Syariah Negara (SBSN), Surat Utang Negara (SUN), Sertifikat Wadiah Bank Indonesia (SWBI) dan obligasi pemerintah maupun swasta semuanya menggunakan instumen uang. Penggunaan uang sebagai instrument utama dalam transmisi kebijakan OPT yang dilakukan oleh BI memberikan celah untuk dispekulasikan oleh lembaga perbankan dan pialang dengan memprediksi kemungkinan harga di masa depan dengan sistem lelang di pasar uang. Dengan demikian resistensi nilai emas sebagai underlying asset uang yang diterbitkan lebih memiliki daya tahan yang baik terhadap fluktuasi perekonomian dibandingkan dengan uang fiat.

Hal tersebut dikarenakan bahwa sistem perekonomian terbuka yang dianut mayoritas negara-negara di dunia saat ini telah menyepakati bahwa uang kertas Dollar Amerika (USD) sebagai mata uang acuan dalam transaksi perdagangan internasional. Mata uang Dollar Amerika dijadikan alat ukur dalam hubungan antar negara ketika melakukan ekspor dan impor, investasi, dan hutang piutang. Dominasi mata mata uang USD dalam perekonomian dunia saat ini menjadi semakin sulit untuk menjadi acuan tunggal dalam transaksi ekonomi antar negara,

${ }^{32}$ Santi Endriani, “Konsep Uang: Ekonomi Islam vs Ekonomi Konvensional,” Anterior Jurnal, Vol XV No. 1, 2015, hlm. 70-75

${ }^{33}$ Toutouchian, Islamic Money and Banking: Integrating Money in Capital Theory, hlm. 7

${ }^{34}$ Toutouchian, Islamic Money...,hlm. 7

${ }^{35}$ Rahmat Ilyas, "Konsep Uang Dalam Perspektif Ekonomi Islam,” Jurnal Bisnis dan Majamen Islam Vol. IV No. 1, 2016, hlm. 38

${ }^{36}$ Pujiyono, "Dinar dan Sistem Standar Tunggal Emas ditinjau Menurut Sistem Moneter Islam.”, hlm. 
sebab flutuasi harga dollar semakin liar dan tidak terkendali. Implikasinya adalah terjadi inflasi yang sangat tinggi bagi negara-negara yang traksaksi globalnya bergantung pada dollar. Sebagai contoh, bencana keuangan yang melanda kawan Asia dari Asian miracle menjadi Asian crisis.

Berkaitan dengan fungsi uang dalam perekonomian suatu negara, ada tiga pandangan yang berbeda dalam mazhab ekonomi Islam ditinjau dari teori permintaan uang. Dalam perspektif ekonomi Islam, sebagaimana yang dirangkum oleh Mahmud dan Rukmana (2010), yaitu: pertama, Mazhab Iqtishoduna, berpandangan bahwa permintaan uang hanya ditujukan untuk dua tujuan yaitu transaksi dan investasi. Kedua, Mazhab Mainstream, permintaan dikategorisasikan untuk transaksi dan berjaga-jaga, ditambahkan bahwa permintaan ini mengarah kepada sumber daya yang ada untuk dikalkukasi dengan maksimum dan efisien. Ketiga, Mazhab Alternatif, permintaan uang berkaitan erat dengan endogenous uang dalam Islam, yaitu keberadaan uang pada "hakikatnya adalah representatif dari volume transaksi yang ada dalam sektor riil". ${ }^{37}$ Pandangan dari tiga mazhab tersebut merupakan saluran yang digunakan untuk perputaran uang adalah dengan memanfaatkan sektor produktif dan menjauhi transaksi keuangan yang bersifat spekulatif.

\section{Peluang Ekonomi Islam}

Distabilitas perekonomian cenderung memiliki implikasi yang tidak baik bagi kesehatan ekonomi negara. Terlebih dengan sistem yang dewasa ini bahwa Dollar Amerika (USD) menjadi salah satu mata uang yang dominan dan diterima oleh seluruh negara dunia. Sebagaimana disebutkan sebelumnya bahwa, mata uang kertas internasional saat ini dipergunakan sebagai acuan perdangangan luar negeri, ekspor-impor, investasi, dan hutang. Sejarah mencatat bahwa setidaknya terjadi 20 kali krisis ekonomi yang melanda perekonomian negera-negara di dunia. ${ }^{38} \mathrm{Hal}$ ini disebabkan beberapa hal, namun yang paling dominan adalah terpakunya kebijakan ekonomi negara-negara tersebut pada suatu mata uang yang fluktuasi sulit untuk dipredksi. Selain itu bahwa, sistem yang digunakan cenderung bersifat spekulatif.

Krisis keuangan di dunia bagian Barat pada tahun 2007 yang lalu telah menyita pemikiran para ekonom untuk merumuskan langkah perbaikan krisis ekonomi yang sedang berjalan, akan tetapi rumusan kebijakan tersebut tidak mampu membuat ekonomi menjadi lebih baik. Walaupun sebagain pemikir menganggap bahwa bahwa solusi yang ditawarkan oleh Islam untuk mensubstitusi sistem kapitalis sebuah yang naif, tapi pemikir Islam harus memngambil langkah sistemik. Hal ini dikarenakan negara-negara muslim memiliki karakter yang berbeda dengan negara lain baik dari aspek warisan, sumber daya abadi, tahap pembangunan dan sistem politik. Langkah tersebut tentunya berdasarkan norma-norma syariah yang bertujuan bukan hanya pada pembangunan akan tetapi transformasi perubahan sosial dengan segala konsekwensinya. ${ }^{39}$ Terlebih kebijakan moneter belum dapat mencapai tujuan dengan baik, hal ini disebab kontradiksi antara transmisi kebijakan dengan tujuan yang ingin dicapai, seperti yang tertera pada tabel 3

${ }^{37}$ Sri Mahrani, Rahmat Richard, dan Darmayuda, "Pengaruh Inflasi dan Produk Domestik Bruto (PDB) Terhadap Tingkat Imbalan Sertifikat Bank Indonesia Syariah (SBIS) Tahun 2009-2012," Jom Fekon Vol. I No. 2, 2014, hlm. 5

${ }^{38}$ Ali Sakti, Ekonomi Islam: Jawaban atan Kekacauan Ekonomi Modern (Jakarta: Paradigma dan Aqsa Publishing, 2007), hlm. 243-4.

${ }^{39}$ Zubair Hasan, "Money Creation and Control from Islamic Perspetive," Munich Personal RePec, no. 73916 Tahun 2011, hlm. 4 
Tabel 3. Jumlah Uang Beredar (M2) di Indonesia dan Tingkat Inflasi Per Desember (milyar rupiah)

\begin{tabular}{cccc}
\hline Tahun & M2 & (YoY) & Inflasi \\
\hline 2018 & $5,760.00$ & $6.3 \%$ & \\
\hline 2017 & $5,419.00$ & $8.3 \%$ & $3.61 \%$ \\
\hline 2016 & $5,005.00$ & $10.0 \%$ & $3.02 \%$ \\
\hline 2015 & $4,546.70$ & $8.9 \%$ & $3.35 \%$ \\
\hline 2014 & $4,173.30$ & $11.9 \%$ & $8.36 \%$ \\
\hline 2013 & $3,717.70$ & & \\
\hline \multicolumn{5}{l}{ Sumber $w$ ww.bi.go.id dan www.bps.go.id } \\
\end{tabular}

Tabel 3 memperliat jumlah uang yang berdar di masyarkat selama periode 6 tahun yaitu 2013 hingga 2018. Terlihat jelas pada tahun 2013 ke 2014 jumlah uang beredar meningkat sebesar 11.9 persen, disaat yang bersamaan bahwa tingkat inflasi mencapai $8.36 \%$ sebagai akibat dari peningkatan jumlah uang yang beredar. Peningkatan dua digit selanjutnya terjadi pada tahun 2016 dimana meningkat sebesar 10 persen dari tahun sebelumnya. Sedangkan tingkat inflasi pada tahun 2017 sebesar 3.36 persen. Peningkatan jumalh uang yang beredar pada periode tersebut juga diringi dengan peningkatnya instumen SBSN dan SUN yang diterbitkan pada tahun-tahun tersebut. Penerbitan SBSN dan SUN dalam rangka mencapai tujuan kebijakan moneter agaknya belum dapat maksimal, hal ini terlihat bahwa pertumbuhan ekononomi stag di angka 5 persen dan pengangguran masih dikisaran 2 digit yaitu 10 persen.

\section{Kebijakan Moneter Islam}

Inflasi merupakan gejala dari ketidak-seimbangan dan hal ini tidak sesuai dengan konsep keseimbangan yang ditawarkan oleh ekonomi Islam. ${ }^{40}$ Oleh karena itu, untuk kembali menyehatkan permasalahan ekonomi adalah dengan menyerang akar permasahan yaitu dengan melakukan shifting konsep transmisi kebijakan moneter. Shifting dilakukan pada konsep inflasi yang tidak adil kepada pinjaman (debtor) nir-riba dan mengikis nilai riil dengan konsep qardhul hasan dapat berlaku lebih adil bagi pinjaman. Hal ini disebabkan konsep qardhul hasan merupakan intrumen pembiayaan yang dapat diperpanjang dan menggunakan mekanisme bagi hasil. ${ }^{41}$ Pada kenyataanya bahwa, mayoritas produk yang dikeluarkan oleh Bank Indonesia (BI) melalui Operasi Pasar Terbuka (OPT) dilaksanakan dengan sistem diskonto. Walaupun dalam penerbitan surat berharga, BI menggunakan diskonto murni dan pembebanan diskonto dimuka. Pada saat transaksi dilakukan, sistem diskonto dihitung melalui rumus: Nilai Nominal dikurangi Nilai Tunai, sementara Nilai Tunai dihitung dengan rumus: ${ }^{42}$

\begin{tabular}{|c|c|}
\hline \multirow[t]{2}{*}{ Nilai Tunai $=$} & (Nilai Nominal) x 360 \\
\hline & $360+$ (Tingkat Diskonto x Jangka \\
\hline
\end{tabular}
1986), hlm. 37

${ }^{40}$ Muhammad Umer Chapra, Towards A Just Monetary System (Leicester: The Islamic Foundation,

${ }^{41}$ Muhammad Umer Chapra, Towards A Just...,hlm. 38

${ }^{42}$ Sugiono, Instrumen Pengendalian ..., hlm. 32 
Sertifikat Bank Indonesia (SBI) yang diterbitkan oleh BI dengan tujuan salah satunya adalah pengendalian inflasi yang uang yang beredar dengan sistem tersebut menimbulkan masalah baru. Dalam artian, apabila SBI diterbitkan dalam rangka kontraksi untuk mengurangi jumlah uang yang berdar dimasyarakat, akan tetapi secara langsung dengan sistem diskonto tersebut BI menciptakan pertumbuhan uang itu sendiri. Sehingga tujuan untuk mereduksi jumlah uang yang beredar sulit untuk dicapai. Terlebih ketika jatuh tempo dan uang tersebut kembali digelontorkan kepada lembaga perbankan, maka yang terjadi adalah jumlah uang yang beredar menjadi lebih banyak dari pada sebelumnya. Menurut para ekonom Islam bahwa sebagian sebagian instrumen dapat digunakan sebagai instrumen untuk mengontrol peredaran uang dan kredit di antarnya adalah reserve requirement, everall and selecting credit ceiling, moral suasion dan change in monetary base. ${ }^{43}$

Dalam rangka mengatasi permasalahan sebelumnya, Chapra telah memberikan beberapa alternatif sebagai dasar pijakan kebijakan ekonomi Islam. Alternatif tersebut dinilai cukup dan tidak berlebihan bagi suatu negara apabila ditinjau lebih hati-hati, diantara alternative tersebut adalah: pertama, Difisit Fiskal, ekstraksi sumber daya dengan cepat dibanding dengan keberlangsungan stabilitas harga cendrung dapat meningkatkan difisit fiskal dan mmpercapat pasokan uang sehingga memicu meningkatnya inflasi. Kedua, Penciptaan pinjaman bank umum, deposit utama yang merupakan basis sistem perbankan, dan deposit turunan dengan jumlah proposional dengan cadangan yang merefleksikan uang bank dalam proses pengembangan kredit, dan disaat yang bersamaan merupakan sumber utama dalam perekonomian. Ketiga, Surplus neraca pembayaran, dewasa ini hanya sebagaian kecil negara-negara muslim yang menikmati surplus dari neraca pembayaran. ${ }^{44}$

Disamping itu, Chapra mengajukan sistem moneter Islam yang berangkat dari kebijakan-kebijakan perspektif sekuler, dan kapitalis, setidaknya terdapat 6 elemen yang harus ada dalam kebijakan tersebut: ${ }^{45}$ pertama, Target pertumbuhan $\mathrm{M}$ dan $\mathrm{M}_{\mathrm{o}}$, mengawali kebijakan moneter Bank Sentral sebelumnya harus menentukan sasaran ekonomi nasional melalui pertumbuhan peredaran uang (M). M memiliki keterkaitan yang cukup erat dengan pertumbuhan $\mathrm{M}_{\mathrm{o}}$, sehingga Bank Sentral harus turun langsung ikut mengawasi velositas likuiditas. Kemudian, uang tersebut dilalokasikan kepada pemerintah, perbankan dan lembaga keuangan lainnya, uang tersebut $\left(\mathrm{M}_{\mathrm{o}}\right)$ di-treatment dengan konsep mudharabah oleh Bank Sentral sebagai instrumen kualitatif dan kuantitatif dalam mengendalikan kredit. Kedua, Uang Giral, maksimum 25 persen demand deposit harus kekelola oleh pemerintah untuk pembiayaan sektor sosial yang menguntungkan. Ketiga, Statutory Reserve Requirement, dalam rangka menjaga likuiditas lembaga perbankan harus memiliki cadangan wajib minimum di Bank Sentral, dan Bank Sentral harus mengganti biaya yang dikeluarkan oleh perbankan. Keempat, kredit Ceiling, kebijakan ini adalah menetapkan batas bagi lembaga perbankan untuk memberikan kredit dalam rangka menjamin penciptaan kredit sesuai dengan target moneter dan komptisi yang sehat antar bank. Kelima, Alokasi kredit berdasarkan nilai, target kredit yang dikeluarkan oleh bank harus mengarah pada peningkatan kesejahteraan masyarakat dengan

\footnotetext{
${ }^{43}$ Mahrani, Richard, dan Darmayuda, "Pengaruh Inflasi dan Produk Domestik Bruto (PDB) Terhadap Tingkat Imbalan Sertifikat Bank Indonesia Syariah (SBIS) Tahun 2009-2012.”, hlm. 6

${ }^{44}$ Dahlia Arika, "Monetary Policy in Perspective of Umer Chapra," Munich Personal RePec, No. 87022, 2018, hlm. 5

${ }^{45}$ Chapra, Towards A Just....hlm. 193-200
} 
memaksimalkan potensi produksi dan distribusi barang dan jasa, kemudian keuntungan dari skema kredit dikembalikan untuk kesejahteraan masyarakat. Pada posisi ini harus adalah jaminan kredit antara pemetintah dan lembaga perbankan guna mengurangi resiko dan biaya yang ditanggung oleh bank, dan. Keenam, Teknik lain, salah satu yang digunakan pada bagian ini adalah himbauan.

Kebijakan ekonomi moneter dalam pespektif Islam setidaknya berangkat dari evaluasi dari sistem konvensional yang nyata secara riil tidak dapat memberikan dampak sigfnifikan dalam mencapai sasaran kebijakan. Ketimpangan pada sistem kapitalis menjadikan jurang pemisah antara kaya dan miskin semakin lebar (economic gap). Terabaikannya hak-hak individu menjadi cacatan besar bagi sistem sosialis. Oleh karena itu, dalam kajian makro ekonomi persepektif Ekonomi Islam, selain menawarkan konsep alternatif dalam melaksanakan kebijakan moneter, padangan ekonomi Islam juga tetap menggunakan transmisi kebijakan pada dua sistem konvensioal selama relevan dan sesuai dengan tujuan peradaban manusia.

\section{KESIMPULAN}

Operasi Pasar Terbuka (OPT) merupakan salah satu instrument kebijakan moneter yang paling sering digunakan oleh Bank Indonesia (BI) dalam rangka treatment stabilitas perekonomian negera. Strategi yang digunakan dalam OPT dapat dilakukan dengan cara menerbitkan Sertifikat Bank Indonesia (SBI), Sertifikat Bank Indonesia Syariah (SBIS), Surat Utang Negara (SUN)/Obligasi Pemerintah, Obligasi Swasta, Intervensi Rupiah (IR), dan Fasilitas Pinjaman Bank Indonesia (FASBI) yang diperjual belikan di pasar uang. Penerbitan surat berharga tersebut sebagian besar menggunakan sistem diskonto. Sistem tersebut dimafaatkan sebagai upaya meng-kontraksi dan ekspansi kebijakan ekonomi dan keuangan. Basis yang digunakan dalam sistem diskonto adalah uang fiat dan tingkat suku bunga.

Tingkat suku bunga yang digunakan untuk mengatur jumlah uang yang beredar tidak sepenuhnya dapat memberikan implikasi berarti dalam pengendalian inflasi itu sendiri. Ketika tujuan kebijakan moneter adalah kontraksi ekonomi, maka kebijakan moneter dirumuskan untuk menarik jumlah orang yang beredar, akan tetapi disaat yang bersamaan kebijakan tersebut menetapkan tingkat suku bunga lebih rendah atas surat berharga yang diterbitkan. Kemudian, ketika jatuh tempo surat berharga tersebut dijual kembali dan memberikan dampak penambahan uang yang beredar secara tidak langsung. Oleh karena itu, basis bunga yang digunakan harus disubstitusi dengan menggunakan konsep dan prinsip syariah yang under-lying penciptaan uang adalah produktivitas. Sebagaimana diusulkan juga oleh Chapra bahwa komunikasi antara pemerintah dan bank sentral menjadi fundamental untuk menjaga stabilitas inflasi. ${ }^{46}$ Limitasi artikel ini belum membahas tentang bagaimana implikasi empiris instrument yang digunakan oleh otoritas dalam menerapkan kebijakan moneter berbasis produktifitas. Oleh karena itu Dalam rangka pengambangan penelitian selanjutnya dapat membahas dampak empiris dari penerapan instrument syariah dalam kebijakan moneter terhadap pertumbuhan ekonomi dan stabilitas inflasi.

${ }^{46}$ Chapra, Towards A Just...., hlm. 205 


\section{E. DAFTAR PUSTAKA}

Arika, Dahlia. 2018. "Monetary Policy in Perspective of Umer Chapra." Munich Personal RePec, No. 87022 .

Ball, Lauraence M. 2012. Money, Banking, and Financial Markets. Second. New York: Worth Publishers.

Bank Indonesia. "Bank Indonesia." Bank Indonesia. Last modified 2018. Diakses Maret 3, 2019. https://www.bi.go.id/id/moneter/inflasi/bi-dan-inflasi/contents/penetapan.aspx.

Belke, Ansgar, dan Thorsten Plleit. 2009. Monetary Economics in Globalised Financial Markets. Berlin: Springer.

Chapra, Muhammad Umer. 1986. Towards A Just Monetary System. Leicester: The Islamic Foundation.

Endriani, Santi. 2015. “Konsep Uang: Ekonomi Islam vs Ekonomi Konvensional." Anterior Jurnal. Vol. XV No. 1

Godley, Wynne, dan Marc Lavoie. 2007. Monetary Economics: an Integrated to Credit, Money, Income, Production and Wealth. Great Britain: Antony Rowe Ltd, Chippenham and Eastbourne.

Hasan, Zubair. 2011. "Money Creation and Control from Islamic Perspetive." Munich Personal RePec, no. 73916

Ilyas, Rahmat. 2016. "Konsep Uang Dalam Perspektif Ekonomi Islam.” Jurnal Bisnis dan Majamen Islam Vol. IV No. 1

Indonesia, Badan Pusat Statistik. Profil Kemiskinan di Indonesia Maret 2018. Jakarta, 2018.

Mahrani, Sri, Rahmat Richard, dan Darmayuda. 2014. "Pengaruh Inflasi dan Produk Domestik Bruto (PDB) Terhadap Tingkat Imbalan Sertifikat Bank Indonesia Syariah (SBIS) Tahun 2009-2012." Jom Fekon Vol. I No. 2 .

N. Grogory Mankiw. 2012. Principles of Macroeconomics. 6th Editio. Mason, USA: SouthWestern Cangage Learning.

Nasional, Subdirektorat Konsolidasi Neraca Produksi. Produk Domestik Bruto Indonesia Triwulan 2014-2018. Jakarta, 2018.

Pujiyono, Arif. 2004. "Dinar dan Sistem Standar Tunggal Emas ditinjau Menurut Sistem Moneter Islam." DInamika Pembangunan, Vol. I No. 2.

Purwanto, Heri. 2013. "Kebijakan Pengendalian Moneter Di Indonesia Dalam Perspektif Perbankan Syariah22." Syariati: Jurnal Studi Al-Quran dan Hukum Vol. III No. 1.

Rachman, Sakinah, dan Sri Herianingrum. 2016."Pengaruh Instumen Sertifikat Bank Indonesia (SBI), Pasar Uang Antar Bank (PUAB), Sertifikat Bank Indonesia Syariah (SBIS), Pasar Uang Antar Bank Syariah (PUAS) Terhadap M2 di Indonesia Periode 20092016." Jurnal Ekonomi Syariah dan Terapan, Vol. V No. 1 .

Sakti, Ali. 2007. Ekonomi Islam: Jawaban atan Kekacauan Ekonomi Modern. Jakarta: Paradigma dan Aqsa Publishing.

Sugiono, F.X. 2004. Instrumen Pengendalian Moneter: Operasi Pasar Terbuka. Jakarta: Pusat Pendidikan dan Studi Kebanksentralan (PPSK) Bank Indonesia.

Toutouchian, Iraj. 2009. Islamic Money and Banking: Integrating Money in Capital Theory. Singapore: John Wiley \& Sons (Asia) Pte. Ltd.,

Warjoyo, Perry. 2004. Mekanisme Transmisi Kebijakan Moneter Di Indonesia. Jakarta: Pusat Pendidikan dan Studi Kebanksentralan (PPSK) Bank Indonesia.

Yanti, Nursantri. 2018. "Pengaruh SBI, Inflasi dan Nilai Tukar Rupiah Terhadap Transaksi Pasar Uang Antar Bank Syariah." At-Tawassuth Vol. III No. 1. 